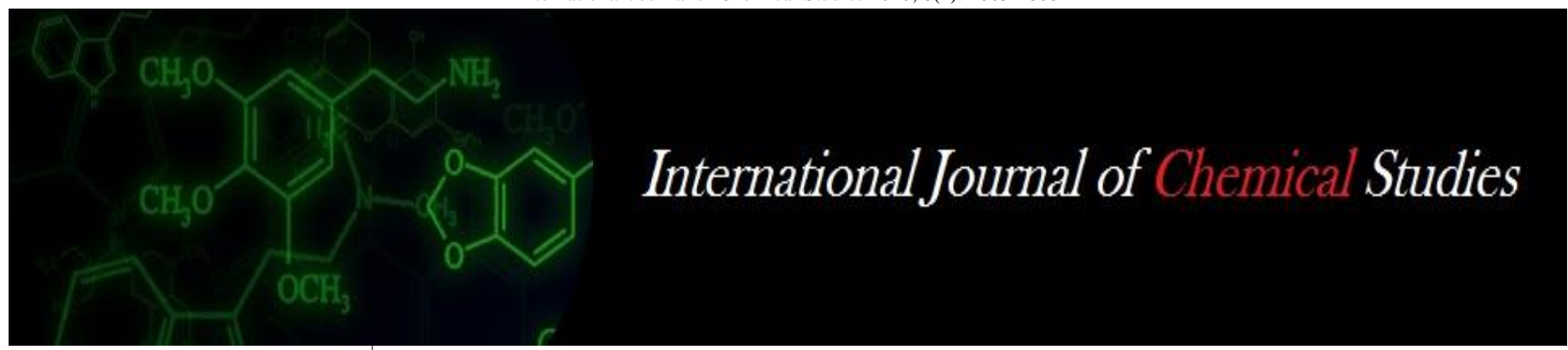

P-ISSN: 2349-8528

E-ISSN: 2321-4902

www.chemijournal.com

IJCS 2020; 8(2): 2863-2868

(C) 2020 IJCS

Received: 16-01-2020

Accepted: 18-02-2020

\section{Rakhi Murmu}

Department of Plant Pathology,

Sam Higginbottom University of

Agriculture, Technology and

Sciences, Allahabad,

Uttar Parades, India

\section{Amit Kumar Maurya}

Department of Plant Pathology,

Sam Higginbottom University of

Agriculture, Technology and

Sciences, Allahabad,

Uttar Parades, India

Vinny John

Department of Plant Pathology, Sam Higginbottom University of Agriculture, Technology and

Sciences, Allahabad,

Uttar Parades, India

\section{Corresponding Author:}

\section{Rakhi Murmu}

Department of Plant Pathology,

Sam Higginbottom University of

Agriculture, Technology and

Sciences, Allahabad,

Uttar Parades, India

\section{Mycoflora of certain casing materials used in the production of white button mushroom (Agaricus bisporus (Lange) Imbach)}

\author{
Rakhi Murmu, Amit Kumar Maurya and Vinny John
}

DOI: https://doi.org/10.22271/chemi.2020.v8.i2ar.9185

\begin{abstract}
In cultivation process of white button mushroom (Agaricus bisporus (Lange) Imbach), casing layer is one of the important parameter and source of variation in production, quality and uniformity of commercial cropping. Mycelia run and change in nutritional status of casing soil is highly correlated with microbial flora. FYM+ garden loam soil (2:1), FYM+ garden loam soil + waste tea leaves (2:1:1), FYM+ garden loam soil + vermi compost (2:1:1), FYM+ garden loam soil $(2: 1)+$ Pseudomonas putida $\left(10^{8}\right.$ c.f.u ml $\left.{ }^{-1}\right)$, FYM+ garden loam soil + waste tea leaves $(2: 1: 1)+$ Pseudomonas putida $\left(10^{8}\right.$ c.f.u ml $\left.{ }^{-1}\right)$, FYM+ garden loam soil + vermi compost $(2: 1: 1)+$ Pseudomonas putida $\left(10^{8}\right.$ c.f.u ml $\left.{ }^{-1}\right)$ were used as casing materials. Available data showed asignificant variety of organisms Papulaspora byssina, Rhizopu sstolonifer, Rhizoctonia solani, Fusarium sp., Trichoderma harzianum, Penicillium sp., Aspergillus niger, Mucor sp., Cladosporium sp. and Verticillium fungicola that were isolated from casing soil of Agaricus bisporus. The most frequently encountered genera were of Trichoderma harzianum followed by Verticillium fungicola.
\end{abstract}

Keywords: Agaricus bisporus, casing soil, mycoflora, Trichoderma harzianum

\section{Introduction}

Mushrooms have been favoured as food by mankind for a long time. Mushrooms supply a rich addition to the diet in the form of protein, carbohydrates, valuable salts, minerals and vitamins (Lakshmipathy et al., 2012) ${ }^{[12]}$. White button mushroom (Agaricus bisporus Lange) is the most popular mushroom species, widely cultivated in temperate countries and cooler regions of the tropics. It requires two different substrates to form the fruiting bodies i.e., the compost for nutrition on which it grows vegetatively and the nutrient deficient casing layer in which the suitable physiochemical/ biological conditions stimulate the initiation process of pin head formation for fruit body formation. This casing soil due to physical, chemical and biological properties used the growth promotion and formation of fruit body and if casing layer is not used, very few mushrooms will be produced (Edabi, 2012) ${ }^{[8]}$. The casing soil functions to supply and conserve moisture for the mushrooms and their rhizomorphs as well as to act as the transport system for dissolved nutrients (Cho et al., 2008) ${ }^{[5]}$. It is an important parameter and source of variation in production, quality and uniformity of commercial cropping (Agrawal and Johri, 2008) ${ }^{[9]}$. A variety of casing materials have been used worldwide, among these, use of farmyard manure (FYM), as a casing medium for mushroom cultivation, has been in vogue in Indian subcontinent because of its easy availability and the non availability of peat moss generally used for casing in Europe and USA (Choudhary, 2011) ${ }^{[7]}$.

Pseudomonas plays key roles in mushroom growth, of which the Pseudomonas putida is regarded as the most significant. Several reports are available on the beneficial effects of casing soil microbes, especially P. Putida and Alcaligenes faecalison A. bisporus (Choudhary et al., 2009) ${ }^{[6]}$. Casing soil inoculated with P. Putida promoted faster growth and more uniform size of primordial (Riahi et al., 2011) ${ }^{[15]}$. Casing layer supports beneficial microbial population that plays a crucial role in mycelium growth, primordium initiation and development, early completion of cropping stages and the yield (Murmu and Lal, 2016) ${ }^{[14]}$. Casing soil has diverse group of microorganisms especially bacteria, fungi and actinomycetes. The number and composition of microorganisms which accompany mushroom cultivation depends on the healthiness of the compost, casing and A. bisporus spawns (Amra et al., 2008) 
[2]. The change in nutritional status of the casing is highly correlated with microbial flora. Role of thermophilic microorganisms in A. bisporus compost production has been studied extensively, however compared to bacteria and actinomycetes, thermophilic fungi have gained more attention (Ahlawat, 2010) ${ }^{[1]}$. Mycoflora present in the casing soil affects the mycelia run and fruit body formation. This study aims to evaluate and identify the mycoflora present in the casing soil.

\section{Materials and Methods \\ Cultivation of Agaricus bisporus:}

Compost was prepared by Long Method of Composting (LMC) using newly harvested wheat straw proposed by Mantel et al. (1972) [13]. Spawn was procured from Department of Plant Pathology, Chandra Shekher Azad University of Agriculture and Technology, Kanpur (U.P). After composting process, thorough spawning was done @ $75 \mathrm{~g} / 10 \mathrm{~kg}$ compost. Seven $\mathrm{kg}(7 \mathrm{~kg} / \mathrm{bag})$ spawned compost weight was filled in the cylindrical polythene bags (size $40 \mathrm{x}$ $40 \mathrm{~cm}$ ) and kept in the mushroom crop room, where temperature ranges between $22-28{ }^{\circ} \mathrm{C}$. Department of Plant Pathology, SHUATS, Allahabad. Compost filled bags were covered with newspaper sheet to prevent loss of moisture content in mushroom beds.

\section{Casing}

The casing mixture stimulates the initiation process of pin head formation for fruiting body formation. Different casing materials used i.e, Farm Yard Manure (FYM), garden loam soil, waste tea leaves, vermi-compost.

\section{Treatments}

1. $\mathrm{T}_{0}-\mathrm{FYM}+$ garden loam soil $(2: 1)$

2. $\mathrm{T}_{1}-\mathrm{FYM}+$ garden loam soil + waste tea leaves $(2: 1: 1)$

3. $\mathrm{T}_{2}-\mathrm{FYM}+$ garden loam soil + vermi compost $(2: 1: 1)$

4. $\mathrm{T}_{3}-\mathrm{FYM}+$ garden loam soil $(2: 1)+$ Pseudomonas putida $\left(10^{8}\right.$ c.f.u ml $\left.{ }^{-1}\right)$

5. $\mathrm{T}_{4}-\mathrm{FYM}+$ garden loam soil + waste tea leaves $(2: 1: 1)+$ Pseudomonas putida $\left(10^{8}\right.$ c.f.u ml $\left.{ }^{-1}\right)$

6. $\mathrm{T}_{5}-\mathrm{FYM}+$ garden loam soil + vermi compost $(2: 1: 1)+$ Pseudomonas putida $\left(10^{8}\right.$ c.f.u ml $\left.{ }^{-1}\right)$.

The pin heads (fruit bodies) started appearing after a week of casing and they took approximately 8-12 days to form the button stage. Mushrooms were picked at the button stage just before the cap expands and the gills are exposed by gently holding them between the thumb and fingers.

\section{Inoculation of bacteria (Pseudomonas putida)}

At the time of casing, bacterial suspensions were inoculated into the casing layer.

\section{Procurement of bacterial culture}

The culture of bacteria (Pseudomonas putida) was procured from Division of Plant Pathology, IARI, New Delhi (ITCC No.-BG-0001). For mass multiplication and growth of Pseudomonas putida, King's B medium was used.

\section{Counting of number of cells of bacteria/ml}

For the counting of bacterial cells/ml, dilution plate technique was adopted. Bacterial cells per ml were counted using the formula:
Number of bacterial cells $/ \mathrm{ml}=$ Number of colonies (average of three replicates) Amount plated $\times$ dilution (Tuite, 1969) ${ }^{[18]}$

\section{Isolation of casing soil mycoflora}

The glass wares (conical flasks, petridishes, test tubes, etc.) were thoroughly washed in detergent power and chromic acid and then air dried. Then petridishes and pipettes were wrapped in the newspaper and sterilized in hot air oven at temperature $160{ }^{\circ} \mathrm{C}$ for 4 hours. For the isolation of mycoflora potato dextrose agar medium (PDA) was used.

\section{Isolation technique}

Casing samples were collected from different treatments and serial dilution technique was adopted (Tuite, 1969) to isolate mycoflora of casing soil. One gram of sample was dried and put in test tube containing $10 \mathrm{ml}$ sterilized distilled water. From this, $1 \mathrm{ml}$ was transferred in test tube containing $9 \mathrm{ml}$ sterilized distilled water through sterilized $10 \mathrm{ml}$ pipettes and same procedure was used to make $10^{-2}, 10^{-3}$ upto $10^{-4}$ dilutions. One $\mathrm{ml}$ was transferred to the petriplates and medium was added and after solidification plates were incubated at $28 \pm 2$ ${ }^{\circ} \mathrm{C}$ for 3-4 days in inverted position. After 3-4 days colonies of the fungus appeared and they were identified on the basis of microscopical and colony characterization.

\section{Identification of mycoflora}

The slides were prepared from the colonies which appeared on the medium after isolation, fungi were identified as Papulaspora byssina, Rhizopus stolonifer, Rhizoctonia solani, Fusariumsp, Trichoderma harzianum, Penicillium sp., Aspergillus niger, Mucorsp., Cladosporium sp. And Verticillium fungicola. These were identified on the basis of microscopically and colony characterization (Gilman, 1957; Barnett and Hunter, 1998; Zare and Gams, 2008) ${ }^{[9,4,19] .}$

\section{Penicillium sp.}

Conidiophores erect, unbranched, septate, at the apex with a vertical of erect primary branches, each with a verticil of secondary (metulate) and sometimes tertiary branch lets or with a vertical of conidia-bearing cells (phialides) borne directly on the slightly inflated apex of the conidiophores. Conidiophores about $300 \mu$ or $400 \times 3.5-4 \mu$, simple or rarely branched, with walls smooth or rough, penicilli long, asymmetrically arranged and $40-50 \mu$ long, branches about $16-$ $26 \times 3-4 \mu$, with walls occasionally roughened, in groups of two or rarely three; metulate about $12-15 \times 2.5-3.5 \mu$ in groups of three to five phialides about $9-10 \times 2-2.5 \mu$, in verticilis of five to ten. Conidia borne in chains which typically form a brush-like head, not enclosed in slime well differentiated foot cells not present. Conidia globose, ovate or elliptical, smooth or rough. Conidia 2.5-3.5 $\times 2.5-3 \mu$ smooth, variously ovate to subglobose, long, adhering in masses (Fig.-1).

\section{Aspergillus niger}

Conidial apparatus developed as stalks and heads form specialized, enlarged, thick-walled hyphal cells (foot cells) producing conidiophores as branches approximately perpendicular to the long axis of the foot cells. Conidiophores non septate, enlarging upward and broadening into elliptical, hemispherical, or globose fertile vesciles bearing phialides, in one series, or as a primary series, each bearing a cluster of two to several secondary phialides at the apex. Phialides parallel arise directly from the substratum, smooth, septate or non septate, varying greatly in length and diameter, 200-400 $\times$ 7 - $10 \mu$ or several millimeters long and $20 \mu$ in diameter. 
Conidial heads fuscous, carbonous black, varying from small, almost columnar masses of a few conidial chains to the more common globose or radiate heads, upto 300,500 or $1,000 \mu$ long; vesicles globose, commonly $20-50 \mu$ up to $100 \mu$ in diameter; phialides typically in two series, thickly covering the vesicle, primary varying greatly in length, secondary 6-10 $\times 2-3 \mu$. Conidia globose to spinulose with colouring substance, mostly $2.5-4 \mu$, less frequently $5 \mu$.Globose, superficial sclerotia produced (Fig.-2).

\section{Rhizoctonia solani}

Hyphae thick, short-celled except for basal strands, branching at right angles and with the formation of cruciform cells, the ascending hyphae usually several times cymosely divided, bearing the terminal basidia in more or less candelabrum-like clusters. Basidia subcylindric, not greatly exceeding in diameter the supporting cells, relatively short, bearing four sterigmata (Fig.-3).

\section{Papulaspora byssina}

The hyphae are septate, branched. Mycelium are light to dark brown producing compact clusters of bulbils which are sclerotium-like and brown in colour, round to oval in shape. These bulbils are interwoven with a fine network of white hyphae (Fig.- 4).

\section{Mucor sp.}

Colonies white to pale grey, sporangiophores formed mostly in restricted marginal areas, rarely branched, hyaline to light brown, arising for the most part from aerial hyphae, oriented in nearly all directions, some collapsing but not bent over; sporangia abortive, globose to short oval, hyaline to brown to black, with a short or long tapering apophysis (Fig.- 5).

\section{Cladosporium sp.}

Hyphae creeping, septate, on the surface or in the substrate. Conidiophores almost erect, branched, and floccose, forming a turf, olive - coloured. The pale to medium olivaceousbrown, smooth to finely veruculose conidiophores are up to $350 \mu \mathrm{m}$ long and $2-6 \mu \mathrm{m}$ wide. The ramoconidia are $0-1$ septate, up to $30 \mu \mathrm{m}$ long and $2-5 \mu \mathrm{m}$ wide, smooth or occasionally faintly rough-walled. Conidia globose and ovate, at first one-celled, then usually with a greenish, terminal and then pressed to the side. The conidia, formed in long, branched chains, are mostly aseptate, limoni form (Fig.-6).

\section{Rhizopus stolonifer}

Stolons at first white later brown. Rhizoids well developed. Sporangiophores erect without branch, brown, 1-5 as a group originating from the opposite side of rhizoids, $900-2700 \mu \mathrm{m}$ in length, $22-32 \mu \mathrm{m}$ in diameter, black. Sporangia globose, 173$235 \mu \mathrm{m}$ in diameter, sporangial wall smooth. Columellae globose, smooth, $153-163 \mu \mathrm{m}$ in diameter. After spores dispersed, columellae mostly depressed to become hemiglobose. Sporangiospores globose-ellipsoidal angular, with many striations running over the surface mainly parallel to the long axis, gray, 7.5-9.6 × 4.3-7.5 $\mu \mathrm{m}$, heterothallic (Fig.-7).

\section{Trichoderma harzianum}

Uniformly branched conidiophores common and forming over $150 \mu \mathrm{m}$ of the length of terminal branches. Branches toward the tip and secondary branches tending to be held at $90^{\circ}$ with respect to the axis from which they arise; further from the tip of the branching system the angle of branching tends to less than $90^{\circ}$ with respect to the axis above. Cells supporting the phialides equivalent in width to, or at most only slightly wider than, the base of phialides arising from them. Phialides typically held in whorls of 2-4 and held at $90^{\circ}$ with respect to the hyphae from which they arise, or solitary; those in whorls typically flask shaped, enlarged in the middle, sharply constricted below the tip to form a narrow neck and slightly constricted at the base. Terminal phialides in a whorl or solitary, typically cylindrical or at least not conspicuously swollen in the middle and longer than the subterminal phialides. Conidia subglobose to ovoidal, lacking a visible basal abscission scar, smooth (Fig.- 8).

\section{Verticillium fungicola}

Vegetative hyphae 1-3 $\mu \mathrm{m}$ wide, sometimes swollen to 3-4.5 $\mu \mathrm{m}$ wide. Sporulation abundant, conidiophores generally arising from submerged hyphae; conidiophores erect, up to over $400 \mu \mathrm{m}$ tall, about $2.5-3.5 \mu \mathrm{m}$ wide at the base, thickwalled, bearing many whorls of 3-10 phialides. Phialides 15$30 \mu \mathrm{m}$ long, from $1.5-2.5 \mu \mathrm{m}$ gradually tapering to $0.8-1.2 \mu \mathrm{m}$. Conidia forming mostly globose heads, oblong, fusiform, long ellipsoidal to almost cylindrical but often with conically tapering and ultimately rounded tips, equal at both ends, usually straight, smooth-walled, of very irregular size, 4.5-8 1.2-2.5 $\mu \mathrm{m}$, with two or more inconspicuous guttules (Fig-9).

\section{Fusarium sp.}

Stroma brownish-white to violet, plectenchymatic, smooth, extended or coloured, green to blue-black by erumpent, sclerotial hard bodies and $0.5-3 \mathrm{~mm}$, or $3-6 \mathrm{~mm}$, in thickness, more or less wrinkled, under medium-high aerial mycelium, later forming sporodochia, more seldom pionnotes with threeseptate spindle-sickle-shaped conidia, curved or almost straight, really or weakly pedicellate. Smaller conidia, one or two celled, oval to reniform, are numerous in the aerial mycelium but are lacking in the typical fruiting layers of the macroconidia. Macroconidia in sporodochia and pionnotes usually three, seldom four to five septet. Microconidia numerous in aerial mycelium. Stroma extended smooth or sclerotial, erumpent, pale or green to dark blue (Fig.- 10).

Table 1: Mycoflora isolated from casing soil of Agaricus bisporus as affected by different treatments (2015)

\begin{tabular}{|c|c|c|c|c|c|c|c|c|c|c|}
\hline Treatment & P. b. & R.s. & Rh. s. & T. h. & F. & Pen. & C. c & A. n. & M. & V.f. \\
\hline $\mathrm{T}_{0}($ Control $)$ & + & + & + & + & - & - & - & + & - & - \\
\hline $\mathrm{T}_{1}$ & + & + & + & + & + & + & + & - & + & + \\
\hline $\mathrm{T}_{2}$ & + & - & - & + & + & + & - & + & + & + \\
\hline $\mathrm{T}_{3}$ & + & - & - & + & - & - & + & - & + & + \\
\hline $\mathrm{T}_{4}$ & - & - & - & + & - & + & + & + & - & + \\
\hline $\mathrm{T}_{5}$ & - & - & + & + & + & + & & + & & + \\
\hline
\end{tabular}


Table 2: Mycoflora isolated from casing soil of Agaricus bisporus as affected by different treatments (2016)

\begin{tabular}{|c|c|c|c|c|c|c|c|c|c|c|}
\hline Treatment & P. b. & R.s. & Rh. s. & T. h. & F. & Pen. & C. & A.n. & M. & V.f. \\
\hline $\mathrm{T}_{0}($ Control $)$ & + & + & + & + & - & - & + & - & - & - \\
\hline $\mathrm{T}_{1}$ & + & + & + & + & + & + & + & + & - & - \\
\hline $\mathrm{T}_{2}$ & + & + & - & + & + & + & - & + & + & + \\
\hline $\mathrm{T}_{3}$ & - & - & + & + & + & + & - & + & + & + \\
\hline $\mathrm{T}_{4}$ & - & + & + & + & - & - & + & + & + & + \\
\hline $\mathrm{T}_{5}$ & - & + & - & + & + & + & - & - & - & + \\
\hline
\end{tabular}

Where:

$\begin{array}{lll}\text { P.b. } & : & \text { Papulaspora byssina } \\ \text { R. s. } & : & \text { Rhizopus stolonifer } \\ \text { Rh. s. } & : & \text { Rhizoctonia solani } \\ \text { T. h. } & : & \text { Trichoderma harzianum } \\ \text { F. } & : & \text { Fusarium } \text { sp. } \\ \text { Pen. } & : & \text { Penicillium } \text { sp. } \\ \text { C. } & : & \text { Cladosporium } \mathrm{sp} . \\ \text { A.n. } & : & \text { Aspergillu sniger } \\ \text { M. } & : & \text { Mucor } \text { sp. } \\ \text { V.f. } & : & \text { Verticillium fungicola }\end{array}$

Trichoderma harzianum was the most prevalent fungus of total fungal species isolated from various casing mixture prepared in the study. Labuschagne et al., (1995) ${ }^{[11]}$ isolated Aspergillus, Penicillium, Trichoderma, Geotrichum, Fusarium and Chrysonilia from the casing soil. Their abundance can be associated by their presence as ubiquitous soil and compost borne saprophyte.

A large majority of total number isolates were member of the genus Verticillium. Unpasteurized or partially pasteurized compost or casing soil or air favors the incidence of this fungus. The pathogen has been invariably isolated from the compost and casing samples collected from mushroom farms in Haryana, Himachal Pradesh and Punjab (Sharma, 1992) ${ }^{[16]}$. Their presence can be associated with the compost containing too much of nitrogen. Carbon di oxide and high moisture are the most favourable factor for growth of Papulaspora byssina. In wet, greasy compost which had not received enough oxygen during fermentation and many of amines, development of the fungus is greatly favoured. Amra et al., 2008 recovered species of Aspergillus, Coprinus, Fusarium, Penicillium, Rhizopus, Sclerotinia, Trichoderma, and Verticillium. Trichoderma and Rhizopus spp. were the most frequently recovered fungi followed by Penicillium spp., whereas Fusarium spp. were the least associated fungi recovered from pasteurizedcasing soil materials.

Asraf et al., (2007) isolated the species of fungus viz., Aspergillus, Trichoderma, Mucor, Rhizopus, Penicillium, Alternaria, Cladosporium, Monilia, Helminthosporium, Coccidoides, Scedosporium from different composts. Jarial and Shandilya (2005) ${ }^{[10]}$ isolated seven species of fungi viz., Aspergillus flavus, A. fumigatus, A. wentii, Penicillium brevicompactum, Cladosporium cladosporoides, Pythium sp. and Mycelia sterilia from different casing materials. Incidence of Papulaspora byssina on the compost of button mushroom was reported from Ludhiana and Pantnagar (AICRP, 2005-06) [3].

Sokovic and Griensven (2006) ${ }^{[17]}$ found that, bacterial and fungal diseases are major problems in mushroom cultivation; a high percentage of products are lost due to lower productivity, decrease of quality and shortened shelf life.

A number of harmful fungi are encountered in compost and casing soil during the cultivation of white button mushroom. Many of these act as competitor moulds there by adversely affecting spawn run whereas others attack the fruit bodies at various stages of crop growth producing distinct disease symptoms. Fungal diseases are major problems in mushroom cultivation, a high percentage of product is lost due to lower productivity, decrease of quality and shortened shelf life. Above all, interaction among developed microorganisms and mushroom mycelia decides fate of mushroom crop.

\section{Conclusion}

Considering the significance of mushroom production in the country and, yet, limited availability of information on casing soil mycoflora, an exhibitive analysis of fungal diversity of this unique material was undertaken. The presence of pathogenic fungi in the cultivation halls at the beginning of the production cycle is a serious threat to the cultivation of mushroom because their rapid development shortens the span of fruiting body harvests. Along with the systematic characterization of fungal communities in casing soil, a functional analysis is needed to highlight potentials and applications.

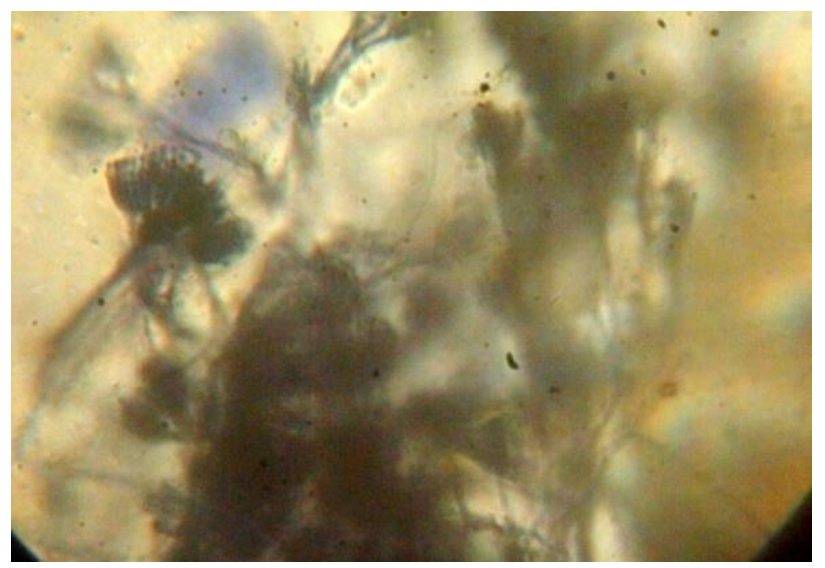

Fig 1: Penicillium sp.

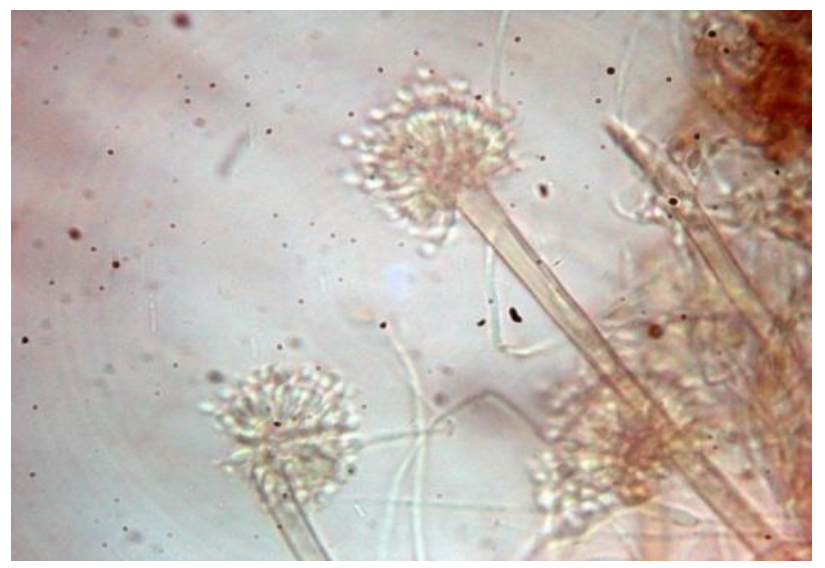

Fig 2: Aspergillus niger 


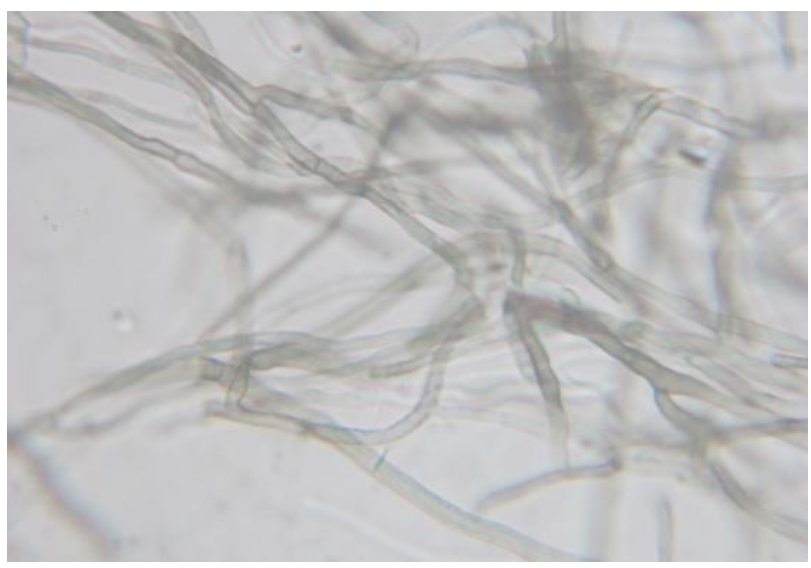

Fig 3: Rhizoctonia solani

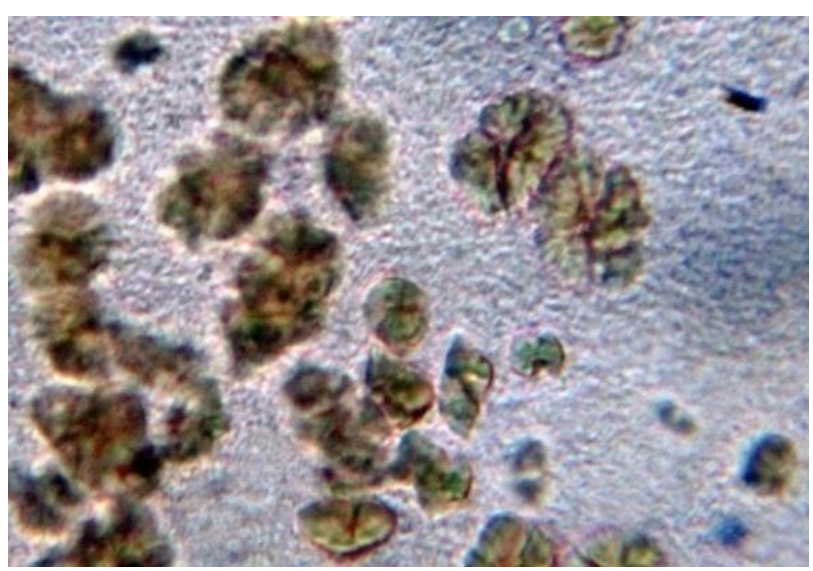

Fig 4: Papulaspora byssina

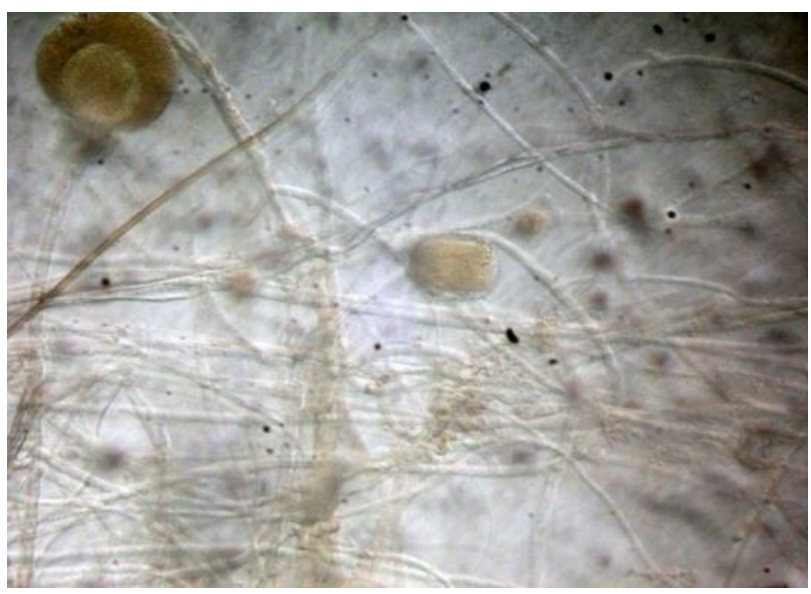

Fig 5: Mucor sp.

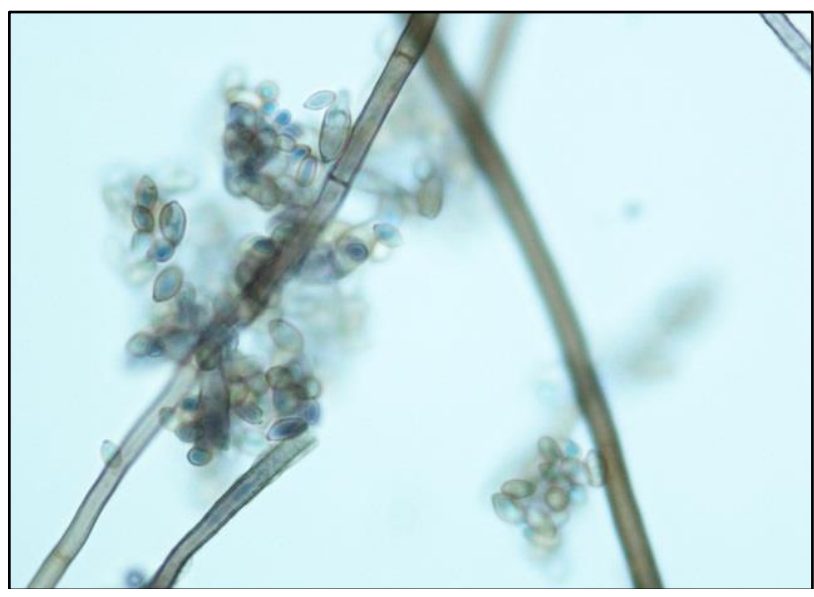

Fig 6: Cladosporium sp.

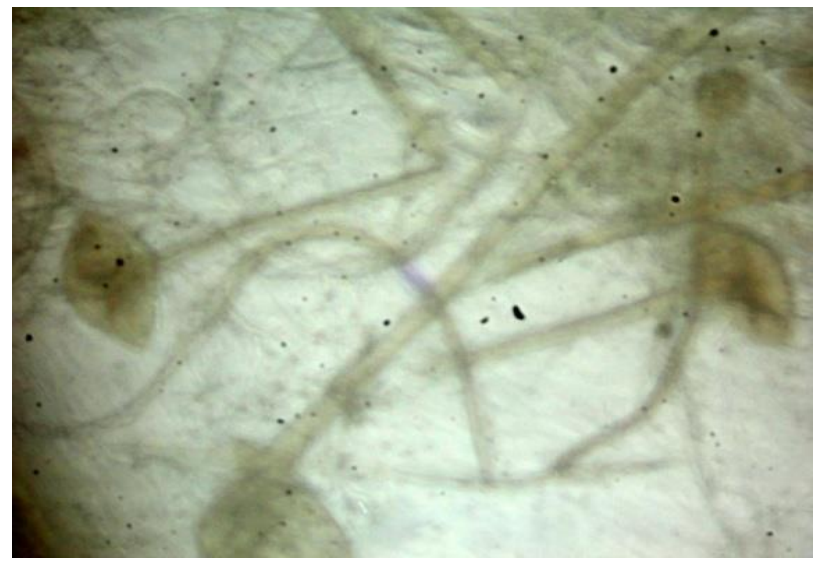

Fig 7: Rhizopus stolonifer

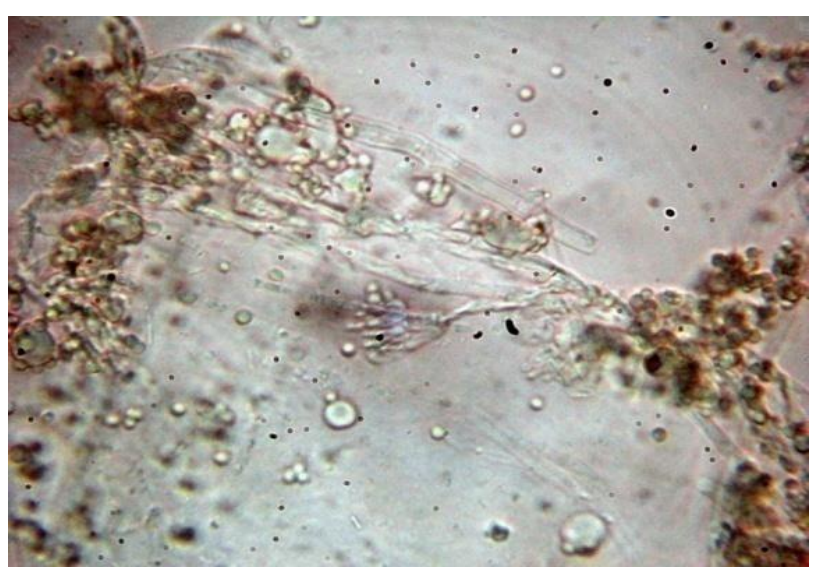

Fig 8: Trichoderma harzianum

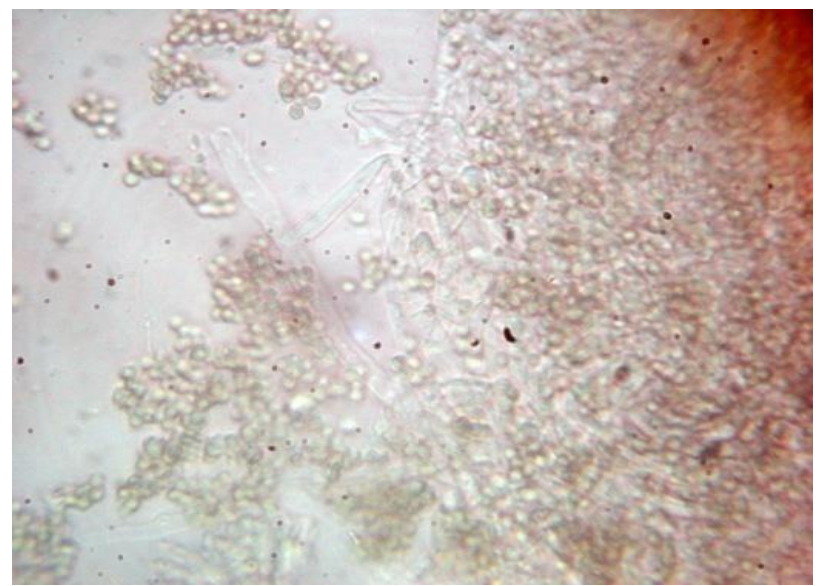

Fig 9: Verticillium fungicola

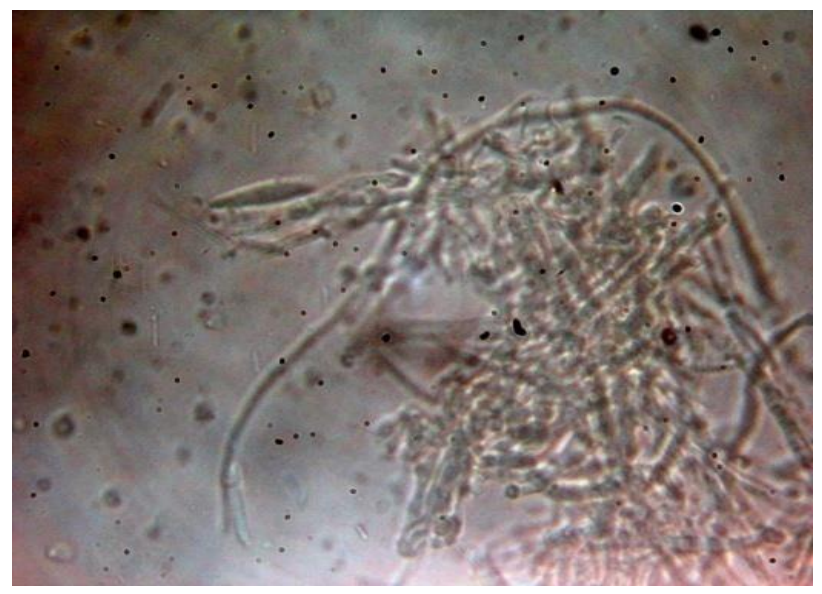

Fig 10: Fusarium sp. 


\section{References}

1. Ahlawat OP, Vijay B. Potential of thermophilic bacteria as microbial inoculant for commercial scale white button mushroom (Agaricus bisporus) compost production. Journal of Scientific and Industrial Research. 2010; 69:948-955.

2. Amra HAS, Bakr AA, Abdulfatah AS, Nogaim QA. Study on microbiological contaminants of Egyptian edible mushroom. Mansoura Journal of Biology. 2008; 35(2):57-70.

3. Annual Report of All India Coordinated Research Project on Mushroom, Solan H.P, 2005-06, 45.

4. Barnett HL, Hunter BB. Illustrated genera of imperfect fungi. The American Phytopathological Society, St. Paul, Minnesota, 1998; 92, 94, 106, 196, 225.

5. Cho YS, Weon HY, Joh JH, Lim JH, Kim KY, Son ES, et al. Effect of casing layer on growth promotion of the edible mushroom Pleurotus ostreatus. Mycobiology. 2008; 36(1):40-44.

6. Choudhary DK, Agarwal PK, Johri NB. Characterization of functional activity in composted casing amendments used in cultivation of Agaricus bisporus (Lange) Imbach. Indian Journal of Biotechnology. 2009; 8:97-109.

7. Choudhary DK. First preliminary report on isolation and characterization of novel Acinetobacter spp. in casing soil used for cultivation of button mushroom, Agaricus bisporus (Lange) Imbach. International Journal of Microbiology, 2011; 1:1-6.

8. Ebadi A, Hossein AA, Mehdi R. Effect of Plant Growth Promoting Bacteria (PGPR) on the morpho physiological properties of button mushroom Agaricus bisporus in two different culturing beds. International Journal of Applied and Basic Sciences. 2012; 3(1):203-212.

9. Gilman JC. A manual of soil fungi.The Lowa State University Press, Ames, 1957; 33, 212, 225, 228, 401.

10. Jarial RS, Shandilya TR, Jarial K. Casing in mushroom beds. Agricultural Reviews. 2005; 26(4):261-271.

11. Labuschagne P, Eicker A, Van GM. In: Science and cultivation of edible fungi (Elliott ed). Balkem, Rotterdam, 1995, 17-22.

12. Lakshmipathy G, Jaykumar A, Abhilasha M, Raj SP. Optimization of growth parameters for increased yield of the edible mushroom Calocybe indica. African Journal of Biotechnology, 2012; 11(11):7701-7710.

13. Mantel EFK, Agarwal RK, Seth PK. A guide to mushroom cultivation unit, In: Handbook of Mushrooms, Directorate of Extension, New Delhi, Ministry of Agriculture, 1972, 63-64.

14. Murmu R, Lal AA. Biochemical estimation and cultivation of Agaricus bisporus (Lange) Imbach on different casing materials and bio-inoculant Pseudomonas putida. Journal of Applied and Natural Sciences. 2016; 8(1):454-458.

15. Riahi H, Eskash A, Shariatmadari Z. Effect of bacterial and cyanobacterial culture on growth, quality and yield of Agaricus bisporus, France In: Proceedings of the 7th International Conference on Mushroom Biology and Mushroom Products; 2011 4-7 October; Arcachon France, 2011, 406-411.

16. Sharma SR. Compost and casing mycoflora from mushroom farms on northern India. Mushroom Research, 1992; 1:119-121.

17. Sokovic M, Griensven Van LJLD. Antimicrobial activity of essential oils and their components against the three major pathogens of the cultivated button mushroom,
Agaricus bisporus. European Journal of Plant Pathology. 2006; 116(3): 211-224.

18. Tuite J. Plant Pathological methods in fungi and bacteria. Burgees Publishing Company, Minneapolis, Minnesota, USA, 1969, 239.

19. Zare R, Gams W. A revision of the Verticilliumf ungicola species complex and its affinity with the genus Lecanicillium. Mycological Research. 2008; 112(7):811824. 